Jpn. J. Med. Mycol.

Vol. 47, 11-14, 2006

ISSN $0916-4804$

原著

\title{
爪白癬からの起因菌同定における培養法と PCR-RFLP法の比較検討
}

\author{
吉 村 理枝子 伊 藤 弥 生 森下 宣 明 \\ 二 宮 淳也滝内石夫 \\ 昭和大学藤が丘病院皮膚科 \\ 〔受付 7 月 14 日, 2005 年. 受理10月20日, 2005 年〕
}

\begin{abstract}
要旨
当科外来を受診した爪白癄患者 100 例から得られた罹患爪の一部をサブローブドウ糖寒天培地に培養し, $27^{\circ} \mathrm{C} に$ て, 最長 2 カ月間観察した。残りの爪サンプルを凍結, 超音波破砕し DNA を抽出, リボゾーム DNA 上の ITS 領域を 用いた PCR おおない, 得られた PCR 産物を Mva I, Hinf I の各制限酵素で消化し, 切断パターンを分析した. ま

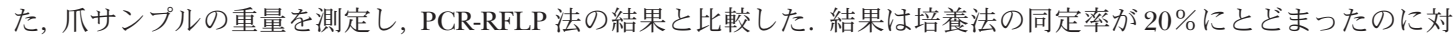
し, PCR-RFLP 法では 73\%であった. 爪サンプルの重量と PCR-RFLP 法での同定結果との間には有意差は認められな かつた. サブローブドウ糖培地を用いた培養による爪白癄の起因菌同定に際し, 菌の viability の問題から培養成功率 の低さが指摘されていたが, 爪サンプルから直接行う PCR-RFLP 法は迅速かつ成功率の高い同定法であると思われ
\end{abstract} る.

Key words: 爪白癄 (tinea unguium), 皮膚糸状菌 (dermatophyte), polymerase chain reaction (PCR), restriction fragment length polymorphism (RFLP), internal transcribed spacer (ITS)

序文

爪白瘷の起因菌同定には, 通常, サブローブドウ糖培 地による培養（以下培養法と略す）がおこなわれている が, その成功率は低い. 近年, 皮膚糸状菌のリボソーム DNA 遺伝子の internal transcribed spacer (以下 ITS と 略す）領域を polymerase chain reaction（以下 PCR と 略す) で増幅し制限酵素分析 (restriction fragment length polymorphism）（以下 RFLP と略す）によって同 定する PCR-RFLP 法が菌種の同定に簡便かつ有用な方 法と報告されている ${ }^{1-3)}$.

今回, 直接罹患爪から起因菌の DNA を抽出し, PCRRFLP 法を用いて同定した結果と, 培養法での結果との 比較を基に PCR-RFLP 法の有用性等について検討した.

\section{材料および方法}

2004 年 7 月から 2005 年 4 月に昭和大学藤が丘病院外 来を受診した爪白癬患者 100 例（男性 59 例，女性 41 例， 年齢 $42 \sim 86$ 歳). 全例共 $\mathrm{KOH}$ 直接検鏡により診断を確 定した. 爪サンプルは初診時, ニッパーを使用して, 病 変部から可能な限りの量を採取した.

別刷請求先：吉村理枝子

†227-8501 神奈川県横浜市青葉区藤が丘 1-30 昭和大学藤が丘病院皮膚科

\section{1. 培養法}

サブロー・シクロヘキシミド・クロラムフェニコール 寒天培地（ペプトン $10 \mathrm{~g}$, ブドウ糖 $20 \mathrm{~g}$, 寒天 $20 \mathrm{~g}$ /蒸留 水 $1,000 \mathrm{ml}+$ クロラムフェニコール $50 \mathrm{mg}+$ シクロヘキ

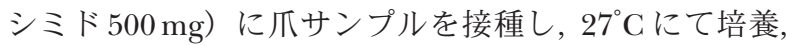
最長 2 ケ月間観察した。培養された菌は, コロニーの形 態およびスライドカルチャー所見から菌種を同定した. 尚, 酵母等コロニーが皮膚糸状菌と思われないものを污 染菌とした. なお, 同定された菌については後述する PCR-RFLP 法にて菌種の確認もおこなった.

\section{PCR-RFLP 法}

(1) DNA の抽出

爪サンプルを液体窒素で凍結した物を乳鉢中で粉砕 し，パウダー状にした後，望月ら 2) の方法に従い，糸状 菌溶解バッファー（200 mM Tris-HCl, pH 7.5, 0.5\% sodium dodecyl sulfate, $250 \mathrm{mM} \mathrm{NaCl}, 25 \mathrm{mM}$ EDTA) $450 \mu l$ を加え, 超音波発振器（UH-50, SMT 社）にてさ らに破砕した. なお, 器具は洗浄後逆性石鹸, エ夕ノー ル消毒し, 乾燥させたものを用いた.これに $3 \mathrm{M}$ sodium acetate $150 \mu l$ を加え, $12,000 \mathrm{rpm}$ で 5 分間遠沈し上清 を採取した。上清に等量の phenol-chloroform-isoamyl alcohol (25:24:1) を加え 2,000 rpm で 10 分間遠沈し 上清を採取した。これに等量の chloroformを加え, 2,000 rpm で 10 分間遠沈した. 上清に等量の 2-propanol 
と ethatinmate（Wako 社） $1 \mu l$ を加え攪挥し, 12,000 $\mathrm{rpm}$ で 10 分間遠沈し DNA の沈殿を得た。沈殿物を乾燥

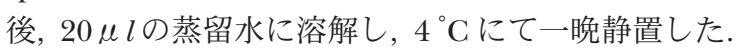

(2) PCR

プライマー ITS-1（5'-TCCGTAGGTGAACCTGCGG, Operon 社) と ITS-4 (5'-TCCTCCGCTTATTGATATGC, Operon 社) ${ }^{4)}$ を用いて増幅した. PCR は $94^{\circ} \mathrm{C}, 4$ 分の変 性後, $94^{\circ} \mathrm{C}, 1$ 分, $58^{\circ} \mathrm{C}, 2$ 分, $72^{\circ} \mathrm{C}, 1.5$ 分を 35 サイクル 繰り返し，2\%アガロースゲルで電気泳動した.

(3)制限酵素による切断

制限酵素 Mva I（Takara 社), Hinf I（Takara 社）で 消化し, 3\%アガロースゲルで電気泳動し, それぞれ UV 照射下で観察した

PCR-RFLP 法の結果, 既知のパターンを示さなかつた 例を污染菌と判断した。 また，爪サンプル重量に対する PCR-RFLP 法での同定成功例と不成功例との間の有意差 について $\mathrm{F}$ 検定および $\mathrm{t}$ 検定をおこなつた.

\section{結果}

培養法および PCR-RFLP 法による同定結果を Fig. 1 に示した。培養法での皮膚糸状菌同定率は 20\%（20例） で，污染菌が 6\%（6 例）培養され，残りの $74 \%$ (74例） は何らの菌も培養されなかつた。同定された菌の内訳は 75\% (15例) が Trichophyton rubrum, 25\%（5 例）が T. mentagrophytesであった。一方，PCR-RFLP 法での同定率 は73\%（73 例)，污染菌は5\%（5 例）であった. 残りの 22 例（22\%） は電気泳動にてバンドが認められなかつ た. PCR-RFLP 法により同定された菌の内訳は, 90.4\% （66例）が T. rubrum, 9.6\%（7例）が T. mentagrophytes であった. 同定不能で污染菌と判定された 5 例を Fig. 2 に示した。この中でU5は培養が陽性で, カンジダ チェック ${ }^{\circledR} に て$ Candida albicans serotype A と同定され た. 培養株を PCR-RFLP 法にて同定したところ U5 と同
様のバンドが認められた. U4, U7, U8, U10 については Fig. 2 に At, Afで示した Aspergillus terreus, Aspergillus flavus をマーカーとして加えた泳動像と一致する像もみ られず，同定不能と判断した．なお，培養法と PCR-RFLP 法との同定結果に相違がみられた例はなかつた。

爪サンプル重量に対する上記の同定不能例（未知の RFLP-pattern）を除いた同定成功例と，PCR で増幅でき なかった不成功例の比較は有意差がなく, PCR-RFLP 法 の成否はサンプル重量に依存しないというものであった

Mk Tm Tr U4 U5 Ng U7 U8 Ng U10 Tr At Af Mk

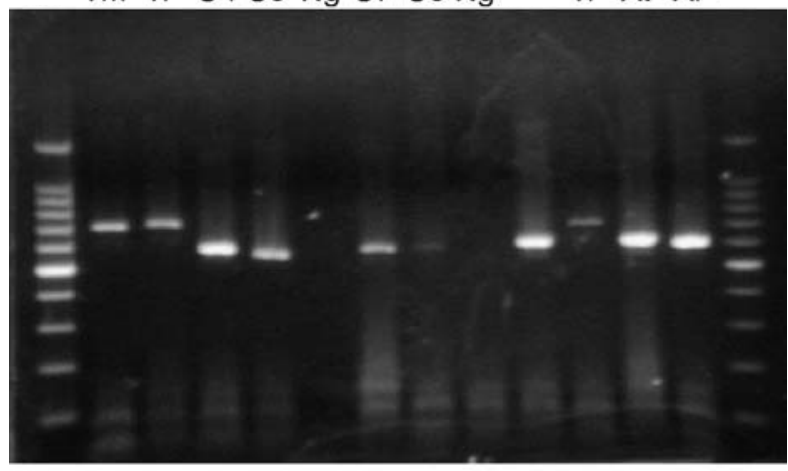

PCR

Mk Tm Tr U4 U5 Ng U7 U8 Ng U10 Tr At Af Mk

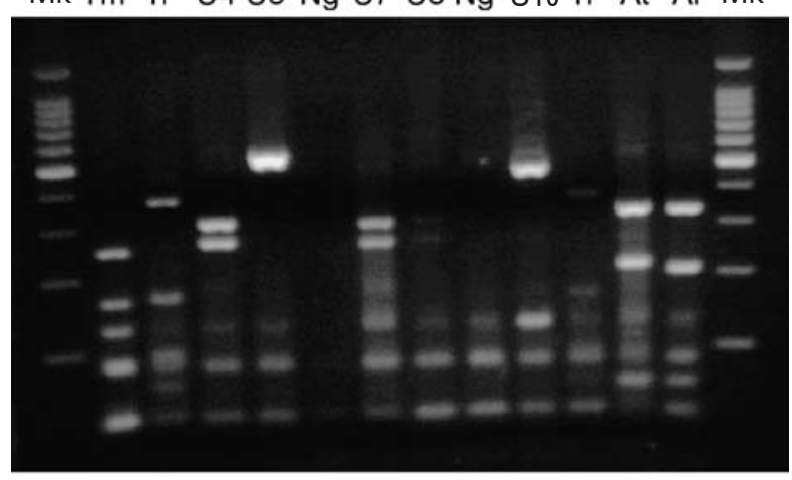

Mva I

Mk Tm Tr U4 U5 Ng U7 U8 Ng U10 Tr At Af Mk

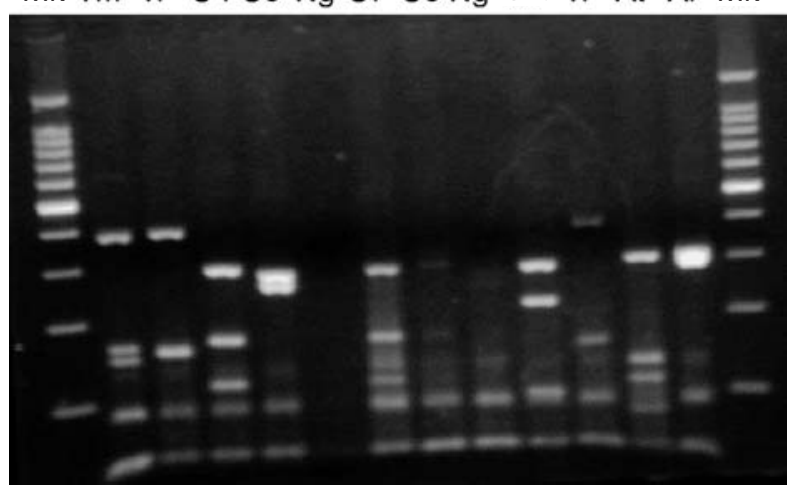

Hinf I

Fig. 2. PCR and RFLP profiles of the samples unidentified. Mk: marker; Tm: T. mentagrophytes; Tr: T. rubrum; U4-10: unidentified; Ng: negative; At: Aspergillus terreus; Af: Aspergillus flavus. $(n=100)$. There was no positive case that showed different species between PCR-RFLP analysis and culture. 


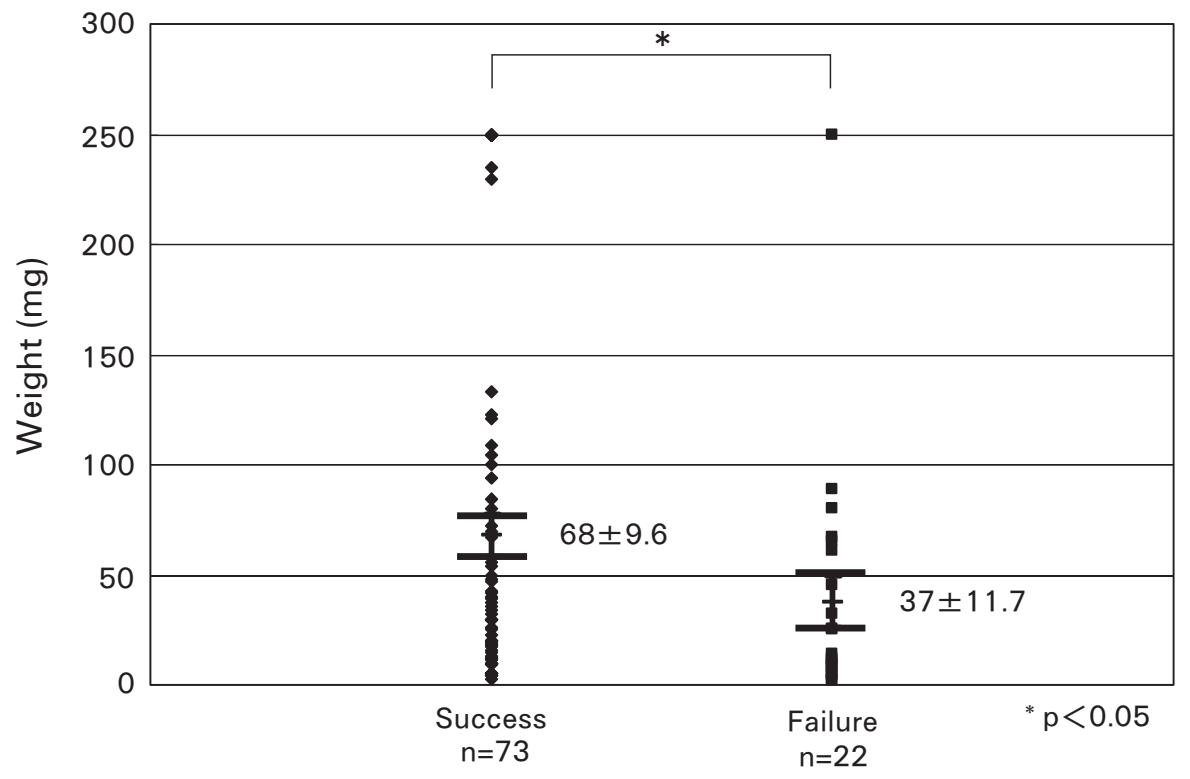

Fig. 3. Weight of nail samples and the result of PCR-RFLP analysis.

(Fig. 3).

$$
\text { 考察 }
$$

爪白癬の培養成功率は低く, 前田ら ${ }^{5)}$ は $20 \%$, 高橋 $ら^{6)}$ は $22.3 \%$, 柴木ら ${ }^{7)}$ は $39.3 \%$ であったと報告してい る. 福田ら ${ }^{8)}$ は, ニュートラルレッド法を用いて, 爪白 癬病巣における皮膚糸状菌の viabilityについて検討し, $\mathrm{KOH}$ 直接検鏡陽性にもかかわらず培養が不成功である 例は, $\mathrm{KOH}$ 直接検鏡にてみられる菌の多くが死菌なの であろうと推定している. ドリルを用いた開空法により 爪の中枢側から爪サンプルを採取すると, 培養率が飛躍 的に向上するとの報告がある ${ }^{9,10)}$.このような培養の手 技により同定率を上げることは不可能ではないとはいう ものの, 日常の外来診療では負担であると思われる. 殊 に，真菌学を専攻する医師以外の皮膚科医が診療に当た る施設においては，培養法によって高い同定率を得るこ とは困難であろう.さらに通常, $\mathrm{KOH}$ 直接検鏡にて診断 を確定する際，培養がおこなわれるが，分離，同定に至 るまでに早いものでも $2 \sim 3$ 週間，遅いものでは 2 ケ月 間と, 長期間を要すことも培養法の欠点の 1 つである.

近年, 病原真菌の同定に PCR 法が用いられている. 望 月ら 2,3) はリボソーム DNA 遺伝子の ITS 領域を PCR で 増幅し，制限酵素 Mva I, Hinf I を組み合わせた制限酵 素分析の有用性を報告している. 爪からの DNA 抽出に 関して, 現在のところ確立された方法はない。一般に組 織片からの DNA 抽出には proteinase K 処理がおこなわ れているが, 爪のような強勒な組織からの抽出には応用 しがたい. 液体窒素を用いた凍結と超音波破砕を加えた 今回の方法は, 簡便かつ充分な結果が得られる方法と思 われた.また, PCR-RFLP 法自体も, DNA 抽出から切断 パターンの分析まで 2 日と迅速な起因菌の同定が可能 であり, 同定率も73\%と優れた結果であった.

同定結果を菌種別に検討すると，T. mentagrophytesの
検出された症例数は, 培養法と PCR-RFLP 法の間に差は 認められなかったものの，T. rubrumの検出された症例 は，培養法15例に対し PCR-RFLP 法 66 例と，4倍以上の 差が認められた。この結果は,爪病巣におけるT. mentagrophytes と T. rubrum の viability に差がある可能性 が高く, 今後検討していく予定である. 爪白癬の起因菌 は圧倒的に T. rubrum が多く，この T. rubrum の同定率 が高いという今回の結果は, 爪白癬の起因菌の同定にお ける PCR-RFLP 法がより優れていることを示すものと 思われた.

今回, 全例 $\mathrm{KOH}$ 直接検鏡にて菌陽性と判定された症 例について検討したが, カンジダチエック ${ }^{\circledR} て ゙ C$. albicans と同定された菌を除き，培養法やPCR-RFLP 法 でも同定できず, 污染菌と判断した症例が数例ずつ認め られた.これらが皮膚糸状菌以外の菌による爪真菌症で ある可能性は否定できないが，仮に皮膚糸状菌以外の真 菌を検出できたとしても，これが病原性を有するものな のか, 腐生しているだけなのかを証明する手段はなく, 今後の課題である. 現在のところ皮膚糸状菌以外の菌に よる爪真菌症の診断には, $\mathrm{KOH}$ 直接検鏡像の仔細な観 察と, 繰り返しの培養が不可欠である ${ }^{11)}$.

PCR-RFLP 法の同定に必要な爪サンプル量について は, 同定の成功例と不成功例の間に統計学的な差はな かつた.この結果から, 得られた爪の中に必ずしも充分 な菌が存在していない, 菌のDNA が変性, 損傷してい た可能性が考えられた。同定率を高めるためには $\mathrm{KOH}$ 直接検鏡で多数の菌が証明された部位を中心に爪を採取 し, より多くの菌の DNA を得る必要があると思われ た.

本要旨は66回 Annual Meeting of Society for Investigative Dermatology（St. Louis, USA, 2005 年 5 月）に て発表した. 


\section{参考文献}

1) Jackson CJ, Barton RC, Evans EGV: Species identification and strain differentiation of dermatophyte fungi by analysis of ribosomal-DNA intergenic spacer regions. J Clin Microbiol 37: 931-936, 1999.

2) Mochizuki T, Tanabe H, Kawasaki M, Ishizaki H, Jackson CJ: Rapid identification of Trichophyton tonsurans by PCR-RFLP analysis of ribosomal DNA regions. J Dermatol Sci 32: 25-32, 2003.

3）望月 隆, 田邊 洋, 河崎昌子, 安澤数史, 石崎 宏: リ ボソーム RNA 遺伝子の ITS 領域の分子型に基づく皮膚 糸状菌の菌種同定の実績. 日皮会誌 114: 1763-1767, 2004.

4) White TJ, Bruns T, Lee S, Taylor J: Amplification and direct sequencing of fungal ribosomal RNA genes for phylogenetics. In PCR protocols: a guide to methods and applications. (Innis MA ed), pp.315-322, Academic Press, London, 1990.

5) 前田 学, 野田徳朗, 森 俊二, 北島康雄, 沢村治樹, 鹿
野由紀子: 岐阜大学皮膚科における最近 2 年間（1991〜 1992 年）の白癬患者一 10 年前の調査との比較検討. 真 菌誌 36: 265-270, 1995.

6）高橋容子，西村和子：君津中央病院皮膚科における最近 6 年間 (1994 1999 年) の白癬菌相. 真菌誌 43: 21-27, 2002.

7）芝木秀臣，芝木晃彦: 札幌市の一診療所における 10 年間 （1992～2001年）の白癬菌相. 真菌誌 44: 209-216, 2003.

8）福田知雄, 塩原哲夫, 仲 弥：Neutral red 染色法を用 いた抗真菌剤の薬効効果－爪白癬への応用一. 日皮会 誌 106: 1313-1316, 1996.

9) Mochizuki T, Kawasaki M, Tanabe H, Ishizaki H: A nail drilling method suitable for the diagnosis of onychomycosis. J Dermatol 32: 108-113, 2005.

10）齋藤卓也，山田一雄，岸本三郎：ラジオ工作用ドリルを 用いた開空法による楔状爪真菌症の診断. 臨皮 58: 586587, 2004.

11）西本勝太郎：Non-dermatophytic onychomycosis. 真菌誌 34: 127-134, 1993.

\title{
Comparative Study between Culture and PCR-RFLP Analysis on Identification of the Causative Agent of Tinea Unguium
}

\author{
Rieko Yoshimura, Yayoi Ito, Nobuaki Morishita, \\ Junya Ninomiya and Iwao Takiuchi \\ Department of Dermatology, Showa University Fujigaoka Hospital \\ 1-30 Fujigaoka, Aoba-ku, Yokohama, Kanagawa 227-8501, JAPAN
}

Background: To identify the pathogenic fungi of dermatophytosis, restriction fragment length polymorphism (RFLP) analysis of PCR amplified ribosomal DNA including internal transcribed spacers (ITS) has been established in Japan. Our purpose was to evaluate the usability of PCR-RFLP analysis to identify the causative agent of tinea unguium directly from a nail sample.

Method: Samples of tinea unguium from 100 nails were collected and cultured on Sabouraud's glucose agar and observed for 2 months. DNA was extracted from these samples, and the PCR product was digested with restriction enzymes Mva I and Hinf I. Weight of the samples was determined.

Result: Sensitivity of PCR-RFLP analysis (73\%) was higher than that of culture (20\%) showing that PCR is more advantageous for identification of the causative agent of tinea unguium. Sensitivity of PCR-RFLP did not depend on weight of the nail sample. 